\title{
癏 MEDIJI I KONFLIKTI U EPOHI GLOBALIZACIJE
}

\author{
Mirko Jakovljević* \\ Visoka škola za komunikacije, Beograd \\ Radenko Šćekić** \\ Univerzitet Crne Gore, Istorijski institut
}

Masovni mediji igraju veoma značajnu ulogu, kako u životima običnih ljudi, tako i na geopolitičkom nivou. Proces globalizacije i tehnološka, komunikacijska dostignuća - doveli su proteklih decenija do pretvaranja planete u „globalno selo“. To je, pored pozitivnih efekata - lakše komunikacije i razmjene ideja, resursa, kultura - dovelo i do negativnih efekata, što se ogleda u prelivanju kriznih situacija (ekonomskih, političkih, migracijskih) širom svijeta. (Zlo)upotreba medija u geopolitičke svrhe je značajno evidentna još od poslednje decenije prethodnog vijeka. Proizvodnja i upravljanje medijskim informacijama je stoga od velikog značaja u savremenom hibridnom ratovanju i konfliktima.

Ključne reči: mediji, konflikti, globalizacija, geopolitika, hibridno ratovanje

\section{Uvod}

Masovni mediji su tehnička sredstva sa velikim mogućnostima širenja poruka ogromnom broju primalaca i igraju veoma važnu ulogu u procesima političkog komuniciranja. Oni su najvažniji posrednik između javnosti i političkih subjekata. Medijem se označava sredstvo komunikacije koje obezbjeđuje širenje poruka od pošiljaoca do primaoca. Termin medij izveden je od latinske riječi medijum koja ima nekoliko značenja: 1) ono što se nalazi u sredini ili što predstavlja sredinu - srednji put, 2) sredina, posrednik, ono kroz šta se dejstvo prenosi (M. Vujaklija, 1980:545). Medij, dakle ima funkciju posrednika, prenosioca poruka i informacija. Za M. Meklauna „medij je poruka, jer način na koji nešto saopštavamo određuje značenje onoga što saopštavamo“ (prema M. Tadić, 2002:160). Važnost medija koju oni danas imaju u brzini prenosa informacija je neosporna, naročito ako se uporedi sa informisanošću u proteklim vijekovima. Tako je vijest o smrti cara Svetog rimskog carstva Fridriha Barbarose, najmoćnije ličnosti Evrope u 12. vijeku putovala od Male Azije do Njemačke 4 mjeseca, a kada je počinjao razvoj štampe u Americi (Boston, 1704), vijesti su objavljivane "tek" sa dva mjeseca zakašnjenja, dok su prve ruske novine (Vejedomosti, 1702.) u vrijeme Petra Velikog imale tiraž od cijelih 300 primjeraka dok je "preko 2.000 britanskih i američkih vojnika poginulo 1815. godine u međusobnom ratu kod Nju Orleansa, jer je vijest o potpisanom primirju u Briselu do njih

\footnotetext{
* Dr Mirko Jakovljević je docent.

** Van. prof. dr Radenko Šćekić je viši naučni saradnik.
} 
putovala 16 dana" (Z. Jeftović, 2003:311). Zemljotres u Lisabonu 1755. je dramatičan primjer kako je razvoj sredstava komunikacija izmijenio način i brzinu širenja vijesti. O ovom zemljotresu u kojem je stradalo preko 60.000 ljudi i koji se smatra jednim od najjačih do sada poznatih u dosadašnjoj istoriji, trebalo je nekoliko mjeseci da se vijesti o njemu rašire po Evropi i dopru do američkih kolonija. Kada su vijesti najzad stigle u luke Bostona i Njujorka, tadašnja štampa ih je samo usputno i kratko spomenula. Da se kojim slučajem nešto slično danas dogodi, vijesti bi bile poslate gotovo brzinom svjetlosti i za nekoliko minuta događaj bi bio propraćen na radiju i televiziji. Video snimci počeli bi da se emituju na TV, uz brojne glasine i promjenljivi broj žrtava. (R. Fidler, 2004:137) Masmediji su stvorili mogućnost trenutne komunikacije između bilo koje dvije tačke globusa - globalnog sela, prema čuvenoj metafori Meklauna. Relativno nizak nivo koncentracije pri gledanju TV programa nastoji se nadomjestiti zvukom, putem najava karakterističnim muzičkim špicama, melodijama koje se koriste da bi se obezbijedio određeni nivo pažnje, jer zvuk mnogo bolje „drži“ pažnju od slike. (D. Mek Kvin, 2000:20) Gledalac se identifikuje sa glavnim junacima, sa njihovim ponašanjem, stavovima, načinom rasuđivanja u određenim situacijama. Na taj način se gledalac identifikuje sa kulturnim i ideološkim osobinama junaka koje su karakteristične za određeni ideološki sistem.

\section{Globalizacijske promjene u medijasferi}

Protekle decenije globalizacije su dovele i do značajnih promjena u medijskoj sferi. Kao i u drugim oblastima društvenih odnosa, konkurencija je u medijskom prostoru je uslovljena tržištem. Informacija dobija svojstvo robe i kao takva se mora prodati što može da bitno utiče i na njenu vjerodostojnost. Odlika tržišta je i surova borba za tržište i publicitet. Televizija ima tu sposobnost da neki događaj direktno prenosi, a za razliku od radija koji to postiže zvukom, ovdje se to postiže zvukom i slikom, čime se uspostavlja direktan odnos između stvarnog događaja i njegovog simboličkog predstavljanja. Pošto se radi o direktnom prenosu događaja, reditelju stoji na raspolaganju mogućnost manipulacije uglovima snimanja, različitim planovima i sl. Korišćenjem kompjuterske tehnike omogućava da se pojedine scene i sekvence isijecaju iz cjeline i ponavljaju više puta u toku samog prenosa čime se ukazuje na željene ključne momente događaja. Stoga Japanski sociolog Šimada ističe - „neophodnost isijecanja i montaže neizbježno deformiše stvarnost da bi je učinila što privlačnijom". (M. Tadić, 2002:222) Reditelj čak i kad želi da prikaže ono što se stvarno zbiva ipak u velikoj mjeri postaje autor reportaže. Mogućnosti manipulacije snimcima su daleko veće nego kod direktnog prenosa nekog događaja. ${ }^{1}$ Stoga se teži „lovu“ na privlačne scene, dramatizaciji prostog događaja i kontinuitetu prizora, i komentatoru koji stvara vezu između sekvenci. Televiziju mnogi teoretičari smatraju glavnim pripovedačkim medijem u savremenom društvu (storing telling medium), koja više nego drugi masmediji utiče na formiranje popularnog diskursa, prihvatanja mitova i narativnih formula važnih za svakodnevni život. (S. Milivojević, 1999:4) Sama riječ manipulacija je novolatinska kovanica (manus-ruka, pulare-ugladiti, udešavati). Manipulaciju mo-

\footnotetext{
${ }^{1}$ Tako su za vrijeme četvrtog izraelsko-palestinskog rata 1973. godine, poznatijeg kao Jom Kipur rat, Izraelci snimke operacija iz prethodnog rata 1967. predstavljali javnosti kao najsvežije izvještaje sa ratišta.
} 
žemo definisati kao neprimjetnu laž u raskoraku sa stvarnim stavom, kodirana da se infiltrira u tuđa mišljenja, ponašanja, vjerovanja, ali bez upotrebe sile. (Jevtović, 2003:25). Tehnike i načela propagande su korišćeni i usavršavani vjekovima.

Poznavanje socijalne psihologije, mentaliteta naroda, ciljanih grupa, njihovih navika, običaja, potreba, analiza i sinteza „korisnih“ informacija - olakšavaju političkim subjektima kreiranje neophodne politike, koncepcije i strategije za preuzimanje ili zadržavanje na vlasti, ali i širenje geopolitičkoj uticaja. Štampa je više od jednog vijeka pokušava da skrati protok vremena između događaja i informacija, dok savremena tehnologija omogućava da se taj razmak izostavi i čak u pojedinim slučajevima da informacija prethodi samom događaju ili barem čeka spremna da se on iscenira i dogodi. ${ }^{2}$ Tokom istorijskog razvoja medije je pratila, u zavisnosti od društvenih prilika, manje ili više, ali konstantno prisutna težnja političkih struktura da ostvare monopol, a time i uticaj na poruku u i javnost. Sredstva komunikacije monopolizovalo je nekoliko onih koji mogu doprijeti do svakoga. Nikada manji broj ljudi nije držao u izolaciji toliko mnoštvo drugih. Sve je više i više onih koji imaju pravo da čuju i vide, ali i sve manje i manje onih koji imaju privilegiju da informišu, izražavaju mišljenje i da ga stvaraju. Diktatura jedne jedine riječi i jedne jedine slike, razara mnogo više od diktature jedne partije - nameće život u kojem je uzorni građanin poslušni potrošač i pasivni posmatrač, izgrađen na proizvodnoj traci sjevernoameričkog modela komercijalne televizije. (Herman/Mekčesni, 2004:4) Novouspostavljenim globalnim medijskim sistemom dominira nekoliko desetina velikih transnacionalnih korporacija (TNC), od kojih su desetak konglomerati sa sjedištem u SAD koji nadziru globalno tržište. (Herman/Mekčesni, 2004:5) Mnogi domeni ljudske aktivnosti prožeti su danas etičkim pitanjima. To je slučaj između ostalog i sa informisanjem čiji je značaj u savremenom društvu toliko jasan da ga uopšte nije potrebno dokazivati, jer po količini vremena koju im savremeni čovjek posvećuje, masovni mediji nalaze se na trećem mjestu, odmah iza rada i sna. (D. Korni, 1999:7) Tehnologija je možda ubrzala stvari ali nije izmijenila ljudsku prirodu.

\section{Geopolitička upotreba medija}

Moderna geopolitika se zasniva na širokoj upotrebi medija u ostvarivanju političkih, ekonomskih, i kulturnih ciljeva. Fundamentalna promjena slike svijeta dogodila se po završetku Hladnog rata, kada nastaje "geopolitika postmoderne“, sa samo jednom supersilom (SAD) i dominacijom zapadnih kulturnih i ideoloških vrijednosti. ${ }^{3}$ Amerikanci,

\footnotetext{
2 "U pokrajini Bijafri je nigerijski pukovnik Azikve koji je od novinara zahtijevao da ga zovu Crni škorpion 1969. godine pogubio izvjestan broj ljudi samo zato da bi specijalni medijski izvještači koji su tu bili prisutni, mogli što prije da snime događaj za svoje reportaže. Takođe su u Vijetnamu američki artiljerci u bazama razbacanim po visoravnima duž granice sa Kambodžom rado predlagali specijalnim izvještačima jedno - "uzbudljivo granatiranje neprijateljskog logora isključivo za potrebe medijskog izvještavanja”, (Frensis Bal, 1997:112).

${ }^{3}$ Prema ovoj interpretaciji, novi „degeografizovani svetski prostor“ postaje područje ekskluzivnog djelovanja preostale supersile koja uspostavlja „novi svjetski poredak“ u skladu sa svojim tumačenjem vrijednosnih kriterijuma poput: demokratije, ljudskih prava, prava nacionalnih manjina, izgradnje multikulturnog društva - ali bez obaveze poštovanja načela međunarodnog javnog prava zasnovanog na konceptu suverenih država. Takvom viđenju stvarnosti savršeno se prilagođavaju mediji. Uloga novinarske profesije mijenja se iz temelja. Umesto nekadašnje cenzure na sceni je „ideologizovano novinarstvo“ u okviru kojeg se od novinara očekuje, ne da prenosi činjenice, nego da činjenice prilagođava idelogizovanoj predstavi koju nameće „duh nove sekularne religije“. Dakle, novinar nije više prenosilac činjenica nego važan ideološki akter u kulturnom ratu širokog spectra Više u: Milorad Vukašinović, Geokultura i mediji, https://www.kcns.org.rs/agora/geokultura-i-mediji/
} 
medijsku manipulaciju usavršavaju čitav prošli vijek. To je kultura u kojoj se, kako je to govorio „otac PR-a“"Edward Bernays ne laže, nego se kreira nova stvarnost. Virtuelna, vještačka, ali ona „ispravlja“ stvarnost u kojoj živimo, u pravcu u kojem manipulatori žele. Da bi protjerali Špance sa Kube, Amerikanci su se 1898. umiješali u sukob načinom koji će se vijek kasnije primijeniti na primjeru Račka ili Markala. Jedne noći je podmetnut eksploziv na američki brod „Mejn“, ukotvljen u havanskoj luci. Španci su demantovali da je to njihovo djelo i zatražili nezavisnu komisiju, a Amerikanci su sve odmah odbili i krenuli u Špansko-američki rat. I kad je predsjednik Vilson riješio da SAD uvede u Prvi svjetski rat, u samoj Americi je sprovedena totalna kampanja koju je vodila čuvena Krilova komisija. Sva štampa je bila uključena u taj poduhvat. Ono što su Hegel i Dejvid Rikardo govorili kao cinizam - ukoliko se stvarnost ne slaže $s$ teorijom, utoliko gore po stvarnost - opredmetilo se u novom dobu. ${ }^{4} \mathrm{Kad}$ su CIA i CNN krajem 1989. rušili Čaušeskua u Rumuniji, javnost je na to gledala kao na trijumf slobode i demokratizaciju. U to vrijeme nikoga nije zanimalo šta je istina o Temišvaru. Posle se ispostavilo da je gotovo sve laž na onoj čuvenoj slici na kojoj nesrećni čovjek plače pored „svoje mrtve žene i djeteta“, ${ }^{5}$ SAD i Sovjetski Savez intenzivno su koristili propagandu tokom Hladnog rata. Obje strane koristile su štampu, film, televizijske i radijske programe i dr. da bi uticali na svoje građane, jedni na druge i na zemlje Trećeg svijeta. SAD-ova Informacijska agencija djelovala je putem Glasa Amerike (VOA) kao službene vladine radio stanice. Radio Slobodna Europa i radio Sloboda, koji su dijelom bili podupirani od CIA-e, koristili su sivu propagandu u vijestima i zabavnim programima. Na sličnom fonu je bila i njemačka DW. Službena vladina stanica Sovjetskog saveza Radio Moskva koristila je bijelu propagandu. Obje strane su, također, koristile crnu propagandu u programima tokom posebnih kriza, kako bi ljudima smanjili (ili po povećali) strah koristeći lažne poruke. Značajnu propagandnu djelatnost u inostranstvu vršila je i informativno-propagandna ustanova bivšeg SSSR-a osnovana 1925. godine pod nazivom Svesavezno udruženje za kulturne odnose sa inostranstvom (VOKS), a od 1958. godine mijenja ime u Savez sovjetskih društava prijateljstva i kulturnih veza sa inostranstvom. Ovaj Savez je bio osnivač sovjetskih domova kulture u raznim državama a cjelokupna aktivnost je bila usmjerena na političke ciljeve u čemu je propaganda igrala prvorazrednu ulogu. Sovjetske domove kulture zamijenili su Ruski domovi nakon raspada SSSR-a.

Primjena propagandnog načela pojednostavljivanja slike svijeta ogledala se tokom perioda Hladnog rata, kroz figuru neprijatelja, u prvom redu Sovjetskog saveza, Kine, Kube, Vijetnama, ${ }^{6}$ da bi se kasnije usmjerilo u pravcu Iraka, SRJ, Sjeverne Koreje, Irana,

\footnotetext{
${ }^{4}$ Koristeći znanja iz psihologija masa, novinar ljavi Li je 1914. u Njujorku otvorio kancelariju za proizvodnju naručenih vijesti. Ta proizvodnja laži će se posle nazvati „public relations“ - PR. Sve je postalo roba, političari, glasači, ideologije - http://www.geopolitika.rs/index.php/sr/intervju/706-2014-03-13-11-00-52

${ }^{5}$ Poslije se ispostavilo da je gotovo sve laž na onoj čuvenoj slici na kojoj nesrećni čovjek plače pored „svoje mrtve žene i djeteta“. Slobodan Reljić, (2014), „Kriza medija i mediji krize”, Službeni glasnik, Beograd.

${ }^{6}$ Mnogo godina nakon rata u Vijetnamu, negdje u periodu 1992. i 1993. došlo je do širenja dezinformacija da jedan KGB fajl sadrži dokumenta koja dokazuju da su Vijetnamci zaista, namjerno zadržali američke ratne zarobljenike kao taoce poslije rata. Ovaj mit su godinama održavali američki političar, Ros Pero i još neki desničari, kao i oni koji su željeli da spriječe normalizaciju odnosa sa Vijetnamom u ime osvete za poraz SAD u tom regionu, D. Kelner, (2004), Medijska kultura, Clio, Beograd, str. 111.
} 
terorističkih organizacija. ${ }^{7}$ Hana Arent je - povodom obelodanjivanja „Pentagonskih papira" (1967) koji su pokazivali kako su Amerikanci u Vijetnamskom ratu najviše obmanjivali sopstvene građane - govorila da legitimisanje laži vodi razaranju razuma koji je najvažniji za našu orijentaciju u stvarnosti. ${ }^{8}$ Po završetku hladnog, prosta podjela na tzv. „slobodni demokratski svijet“ i tzv. „kraljevstvo zla iza gvozdene zavjese“ više nije bila održiva. Tako su se tvorci javnog mnjenja na zapadu našli pred određenim teškoćama, jer do tada važeća paradigma više nije bila efektna, pa je postalo teže političkim elitama da dobiju javnu podršku za određene spoljnopolitičke planove i akcije. Kao ključni problem nametnuo se definisanje stanja stvari, nakon nestajanja decenijama održavane paradigme. Zato se poseglo za intenzivnom i agresivnom kampanjom, putem medija i PR agencija da publici nametne željena projekcija stvarnosti. Brojnim vojnim i humanitarnim intervencijama SAD, nastoje da prošire svoj uticaj u svijetu, a u tom smislu vode se sledećom logikom - SAD moraju istrajati u svom istorijskom zadatku jedine supersile, dok se pri tome okreću drugima da plaćaju račune održavanja svjetskog reda i mira. ${ }^{9}$ Takođe je jasno da i pored ovako impozantne vojne sile, kreatori politike SAD moraju pribjegavati propagandnim tehnikama kako u svijetu tako i kod kuće, u čemu im na raspolaganju stoji neslućena moć današnjih medija, kako bi u javnom mnjenju stekli podršku za svoju politiku. Već za vrijeme R. Nixona postaviće se pitanje da li on uopšte vlada ili mu je samo stalo da bude predsjednik (Z. Slavujević, 2005:40). Analiza teksta Zalivske krize 1991. nagovještava da su od početka vodeće medijske institucije slijedile pravce Bušove administracije i Pentagona. Mejnstrim mediji u SAD su komercijalni mediji, među kojima vlada žestoka konkurencija u pogledu gledanosti i profita. Posledica toga je da ovi mediji ne žele da odbiju potrošače, zbog čega su izuzetno oprezni u izražavanju mišljenja koje je suprotno mišljenju javnosti i zvanične vlasti. Oni takođe daju prednost zvaničnim izvorima vlasti u pogledu informacija, naročito u doba krize, i na taj način oni postaju prenosioci politike i stavova vlade. ${ }^{10}$ lako su vodeći mediji poslužili kao propagandno sredstvo američke vlade i vojske, oni nisu isključivo propagandni instrument države. „Istina se danas ne kotira dobro u moralnom poretku". Takav stav je prije nekoliko godina ilustrovao jedan službenik za odnose sa javnošću jedne od 10 najvećih američkih korporacija - „Da li riječ laž, uopšte više znači nešto. U jednom smislu, svi lažu ali u drugom smislu niko ne laže

\footnotetext{
${ }^{7}$ U SAD je antiarapska propaganda postao veoma tražen komercijalni proizvod. Jedna tiražna majca prikazuje američkog marinca koji je uperio pušku u Arapina oborenog na zemlju, sa natpisom „Pošto ti je sad nafta!" Na jednoj majici je pisalo: „Dođi u vojsku, posjeti zanimljiva mjesta, upoznaj zanimljive ljude i ubij in“, D. Kelner, (2004), Medijska kultura, Clio, Beograd, 2004, str. 364.

${ }^{8}$ Tada su Amerikanci shvatili da su im mediji o Vijetnamu javljali samo laži, Arent je opisala kao psihotično triježnjenje: „Uvijek se dolazi do tačke posle koje laganje daje suprotne rezultate. Do te tačke se dolazi kad je publika, kojoj se laži upućuju, prisiljena da potpuno odbaci razliku između istine i laži da bi preživjela.", http://www.politika.rs/rubrike/Komentari/Ono-nase-sto-nekad-bejase.It.html

${ }^{9}$ Svjedočeći pred Kongresom, pomoćnik državnog sekretara L. Iglberger je objašnjavao da će Novi svjetski poredak koji se pojavljuje, bazirati na nekoj vrsti novog izuma u sprovođenju diplomatije: "tako što će drugi plaćati troškove intervencija SAD u održavanju reda." (N. Čomski, Kontrolisana demokratija, CID, Podgorica, 1999, str. 20).

10 "Pod mejnstrim medijima u SAD podrazumijevaju se glavne nacionalne televizijske mreže, među kojima su ABC, CBS, CNN, i NBC, nacionalni nedjeljni časopisi - Time, Newsweek, i U.S. News and World Report, i nacionalne dnevne novine - New Jork Times, The Wall Street Journal, USA Today i Washington Post" - (D. Kelner, $2004:$ 331).
} 
pošto niko ne zna šta je istina - šta god vam izgledalo uredu." (L. A. Dej, 2004:100). Želimo li kontrolisati društvo moramo kontrolisati informacije - mogla bi biti jedna od krilatica ovakvih elita. lako su vodeći mediji poslužili kao propagandno sredstvo američke vlade i vojske, oni nisu isključivo propagandni instrument države. ${ }^{1}$

Uloga savremenih medija u kreiranju dnevne politike je ogromna. Javnost $\mathrm{i}$ javno mnjenje je dobilo svoju ulogu i širi značaj pojavom pomenutih medija. Pojave kao što su medijski pritisci su prouzrokovale da se političari ponašaju odgovornije. „Nikada ne dozvolite da 'kriza' propadne!" (tj. da je ne iskoristite), famozno je izjavio bivši Obamin saradnik u Bijeloj kući R. Emanuel. lako za neke novitet, ovo je nešto što ljevičari u Sjedinjenim Američkim Državama praktikuju već dugo vremena i za javnost u SAD-u nije ništa novo. ${ }^{12} \mathrm{U}$ posthladnoratovskoj američkoj doktrini posebno je politika zaštite ljudskih prava postala moćno sredstvo uticaja na politiku određene zemlje. Već je 1990. američki predsjednik G. W. Bush retorikom zaštite ljudskih prava, moralnosti, jedinstva, pravde i zakonitosti - osigurao uspostavljanje široke vojne koalicije tokom napada na Irak. Bil Clinton upravo na zaštiti ljudskih prava temelji praksu humanitarnih intervencija (Somalija, 1993; Haiti, 1994; Bosna, 1995; Jugoslavija, 1999;), nakon čega ljudska prava postaju neobično i obilato "upotrebljiva" u geopolitici 21 . vijeka. ${ }^{13} \mathrm{U}$ tom kontekstu zaštita ljudskih prava postaje formalni temelj zapadnog intervencionizma, kojim se oblikuju političke prilike u zemljama evropske periferije (Ukrajina, Makedonija, Kosovo) ili se na prostoru Sjeverne Afrike i Bliskog istoka nasilno ruše nepodobni režimi, instaliraju novi, doktrinom "kontrolisanog haosa”. Naravno, u politici se ništa ne dešava „slučajno" ni „spontano“, a iako se dogodi - to je unaprijed već dogovoreno, poput "Arapskih proleća”. "Sličan geopolitički sukob regionalnih geopolitičkih igrača vodi se danas u Jemenu (suparništvo Irana i Saudijske Arabije). Naučivši proteklih decenija Zapadne tehnike i stil medijske borbe, Ruska federacija se tokom Ukrajinske krize i Krimskog pitanja pokazala superiornija u

${ }^{11}$ Po N. Čomskom: "SAD su istovremeno najslobodnije društvo na svijetu, a sa druge strane demokratija u SAD ima svoja tamna mjesta - najslobodnije je istovremeno jedno od najdublje indoktrinisanih društava svijeta", što po njemu nije ništa paradoksalno, jer baš zato što je slobodno, njime se mora vladati putem perfidne indoktrinacije (N. Čomski, Kontrolisana demokratija, CID, Podgorica, 1999, str. 20).

${ }^{12}$ Iskorišćavanje javnih/ društvenih tragedija (nesreća, socijalnih nemira, neimaštine, nezaposlenosti, nacionalizma i dr. kolektivnih pojava) u medijske i promotivne svrhe je nešto što političari svaki put rado iskoriste kako bi "okrivili" drugu stranu i time privukli nove glasače željne senzacije. http://balkans.aljazeera.net/makale/kultura-komuniciranja-i-izborne-kampanje

${ }^{13}$ Ugledni njemački sociolog Ulrich Beck, režim zaštite ljudskih prava smatra vrlo djelotvornom strategijom koja "revolucionira svjetski politički poredak" na način da meta-moć globalnog civilnog društva (NVO), kao novog subjekta međunarodnih odnosa, nametanjem pitanje zaštite ljudskih prava urušava autonomiju nacionalne države. Nacionalna ili socijalna prava gube prednost pred režimom zaštite ljudskih prava čime se otvara bezgranični prostor moći svjetske unutrašnje politike u kojem se zapadne, globalno uticajne države, ali i nevladine organizacije koje su pod zapadnom kontrolom - vrlo intenzivno miješaju u unutrašnju politiku drugih, na način da mogu mijenjati njihove strukture vlasti. Beck govori o "mješovitom obliku humanitarne nesebičnosti i imperijalne logike meke i tvrde moći, naročito iskazane u vojnim tzv. humanitarnim intervencijama, kako teme globalnog civilnog društva poput zaštite ljudskih prava, često bivaju instrumentalizovane od strane Sjedinjenih Država, Europske unije kao i drugih globalnih aktera", Jadranka Polović: Ljudska prava kao formalni temelj intervencionističkih politika http://geopolitika.news/analize/dr-scjadranka-polovic-ljudska-prava-kao-formalni-temelj-intervencionistickih-politika-3-dio/

${ }^{14}$ Sukob u Angoli koji je tinjao nekoliko decenija tokom druge polovine XX vijeka, predstavlja karakterističan primjer geopolitičke upotrebe jednog prostora, kroz formu borbe za slobodu i ostvarivanja željenih ljudskih prava - Hironaka, Ann (2009). Neverending Wars: The International Community, Weak States, and the Perpetuation of Civil War. Harvard University Press. 
ovom hibridnom ratu. lako je očigledno da ni Zapad u hibridnom ratu sa Rusijom ne zaostaje, bar kad se pogleda vještačko obaranje cijene nafte i gasa, obaranje vrijednosti rublje u Rusiji - NATO sve otvorenije priznaje da je Rusija pokazala da umije da vodi „hibridni rat", kako tvrdi zamjenik komandanta NATO snaga u Evropi general Edrijan Bredšou. ${ }^{15}$ Kriza u Ukrajini ubrizgala je novu dozu adrenalina u NATO i pružila mu novo opravdanje postojanja. Jedno od ključnih sredstava u medijskom spinu prilikom izveštavanja iz ukrajinskog i sirijskog konflikta je prilično fleksibilna terminologija koju u svojim izveštajima koriste. Poslednji lider Sovjetskog Saveza Mihail Gorbačov je istakao, da postoje svi znaci da je blizu novi Hladni rat. U intervjuu za njemački Bild Gorbačov je rekao da je u toku nova trka u naoružanju i za porast tenzija optužio Zapad koji, kako je rekao, nije ispunio obećano Rusiji. „Jezik koji koriste političari i visoki zvaničnici vojske postaje sve više ratoboran. Vojne doktrine se formulišu sve oštrije. Masovni mediji se priključuju i dolivaju ulje na vatru. Odnosi velikih sila su sve gori. Stvara se utisak da se svijet priprema za rat. Tako da imamo sve znake Hladnog rata", rekao je Gorbačov. ${ }^{16}$ Medijski geopolitički rat je danas najvidljiviji na prostoru Sirije, Ukraine, Baltika.

Svakodnevno smo svjedoci spinovanih informacija, optužbi, demantija i sl. Zapadni mediji optužuju Rusku federaciju za agresivnost prema susjedima, miješanje u izbore ${ }^{17}$, za brutalnost ili prikrivanje gubitaka u Siriji i sl. Sa druge strane, ruski mediji pokazuju dobru organizovanost i efikasnost u ovom hibridnom ratovanju, agresivno djelujući u medijskom i političkom prostoru drugih zemalja. ${ }^{18}$ Moglo bi se istaći, da su imali od koga učiti proteklih decenija: od CNN, BBC, Reutersa, DW, pa sve do istraživačkih rezultata i analiza Rand fondacije, Stratfora i Tavistok instituta. Geopolitičke namjere se ostvaruju informisanjem i upravljanjem komunikacijama. Borba za životne prostore nikako nije apstraktna, već složena, kamuflirana i propagandno - retorički maskirana bitka političkih rivala koji neprekidno odmeravaju odnose snaga. Globalni uticaji ostvaruju se preko medija a u javnom diskursu vladaju demagogija, propaganda i brutalnost. Distribucijom komunikacione moći ostvaruje se poželjno javno mnjenje. ${ }^{19}$ Tako da mi se moglo dijagnostikovati da

\footnotetext{
${ }^{15} \mathrm{Na}$ optužbe da Moskva vodi hibridni rat reagovao je i stalni predstavnik Rusije u NATO-u Aleksandar Gruško, koji je istakao da NATO ima dugu istoriju „hibridnih operacija”, a kao primjere je naveo operacije u bivšoj Jugoslaviji i Libiji: „Bili smo svedoci vrlo dobro poznatih znakova vojnih ucjena, tajnih intervencija, snabdijevanja oružjem i diplomatskog licemerja, manipulacije masovnim medijima i eksplicitnog širenja dezinformacija u bivšoj Jugoslaviji i Libiji 2011.” - „Hibridni rat i Rusija“, Politika, 22.03.2015.

${ }^{16}$ Gorbačov je rekao da je Zapad prevario Rusiju poslije okončanja Hladnog rata i da nije ispunio dogovor da se NATO ne širi dalje na istok. „Zapad“, a prije svih SAD, odustao je od sporazuma http://www.vijesti.me/svijet/gorbacov-svi-znaci-da-je-blizu-novi-hladni-rat-934168

${ }^{17}$ Česte su optužbe od strane bivših američkih zvaničnika protiv Ruskog Instituta za Strateške studije da su objavljivanjem određenih poverljivih informacija, uticali na američko javno mnenje uoči novembarskih predsjedničkih izbora 2016 godine.

${ }^{18}$ Rusija je u okviru armije stvorila specijalnu vojsku za „informativne operacije“, izjavio je ruski ministar odbrane Sergej Šojgu. "Stvorena je vojska za informacione operacije, što je mnogo efikasnije, jače", rekao je Šojgu obraćajući se poslanicima Državne Dume. Naveo je da „propaganda mora da bude inteligentna, ispravna i efikasna“,

http://www.rts.rs/page/stories/sr/story/10/svet/2640250/sojgu-ruska-vojska-nastavlja-sa-modernizacijom.html

${ }^{19}$ Globalna moć se ogleda u sposobnosti medija da dramatizuju planirane političke spektakle i tako stvaraju „svijest globalne zajednice”. Tehnika u „zavođenju masa” je mnogo savršenija u doba globalizma, manipulativne tehnike i trikovi su sofisticiraniji u stvaranju privida. Institucionalna laž je dozvoljena samo velikim geopolitičkim igračima - Despotović, Lj, Jevtović, Z. Geopolitika i mediji, Kultura polisa, Grafomarketing, Novi Sad, 2010.
} 
je upravo sloboda medija, pravo na informisanost - jedno od najugroženijih ljudskih prava. A da je realna vlast - tajna vlast. Novac je samo u funkciji moći u čijoj osnovi leži ovaj ili onaj sistem ideja.

\section{Zaključna razmatranja}

Masovni mediji imaju veliku ulogu u kreiranju javnog mnjenja, naročito u procesima političke komunikacije. Ono što mediji prenose više nije „prenešena“ realnost već je "medijski kreirana" realnost - simulacrum. Politički lideri se prioritetno preko medija obraćaju svojim potencijalnim glasačima kroz formu političkog marketinga, politički lideri kreiraju svoj imidž - sliku o sebi. Kroz vidove političkog marketinga, imidžu političara i njegovo kreiranje pridaje se veliki značaj. Tako se imidž odvaja od identiteta i postaje svojevrsna maska pod kojom se politički subjekt predstavlja biračima. Izbori postaju zavisni od procjena koje birači stvaraju na osnovu medijskih informacija koje dobiju o političarima-kandidatima. Političkim marketingom se reklamira i prodaje određena politička ideja. Političko-markentinške kampanje usmjerene su prije svega na publicitet u medijima. Političko tržište je slično ekonomskom. A svako tržište funkcioniše na bazi privatnog interesa. Za formiranje, učvršćivanje ili promjenu stavova o političkim događajima, koristi se političko ubjeđivanje (peruazivna komunikacija). Željena politika se može veoma efikasno plasirati građanima pomoću medija koji mogu veoma brzo i uspješno da prenesu ideju vodeće političke strukture na najveći broj čitalaca, gledalaca i slušalaca i da na taj način omoguće usmjeravanje razmišljanja i činjenja.

Mediji se koriste kao sredstvo kontrole stvarajući neophodnu iluziju, često i u zabavnoj formi, koja je u interesu određene politike. ${ }^{20}$ Mediji, naročito televizija, imaju „trajniju” i opštu, prije nego konkretnu i formalnu ulogu u formiranju stavova i pretpostavki neophodnih za učešće ljudi u društvenom životu. Prema M. Radojković (2005:196) „stavovi su armatura ljudskog ponašanja jer se u njima krije voljni naboj koji će psihomotorički da nagna ljudsko biće da nešto fizički ili duhovno učini ili ne učini. Mehanizam promene ponašanja prati i manifestuje procese rekonstrukcije stavova". Primjena propagandnog načela pojednostavljivanja slike svijeta ogledala se tokom perioda Hladnog rata, kroz figuru neprijatelja, u prvom redu Sovjetskog saveza, Kine, Kube, Vijetnama, da bi se kasnije usmjerilo u pravcu Iraka, SRJ, Sjeverne Koreje, Irana, terorističkih organizacija. Po sistemu - sami kreiramo problem/neprijatelja, organizujemo ga - i onda ga se rješavamo/borimo se protiv njega - pri čemu su zaposleni vojnoindustrijski kompleks i vodeći mediji.

\section{Literatura}

[1] Bal, F. (1997), Etika informisanja, Clio, Beograd.

[2] Čomski, N. (1999) Kontrolisana demokratija, CID, Podgorica.

\footnotetext{
${ }^{20}$ Jer "politika nije nauka ni umjetnost, već igra za moć i igra sa moći. Ta igra nije zabava, već smrtno ozbiljna stvar u kojoj su smrt, fanatizam i kalkulacija češći od humora i smijeha” (S. Orlović, 2002:109).
} 
[3] Despotović, Lj, Jevtović, Z. (2010) Geopolitika i mediji, Kultura polisa, Grafomarketing, Novi Sad.

[4] Grupa autora, (2004) Amnezija javnosti - od propagande do terorizma, Grafo komerc, Beograd.

[5] Hironaka, Ann (2009). Neverending Wars: The International Community, Weak States, and the Perpetuation of Civil War, Harvard University Press.

[6] Jevtović, Z. (2003) Javno mnjenje i politika, ALU, Beograd.

[7] Kelner, D. (2004), Medijska kultura, Clio, Beograd.

[8] Korni, D. (1999), Etika informisanja, Clio, Beograd.

[9] Milivojević S. (1999), Medijska manipulacija političkom javnošću, (doktorska disertacija), Nikšić.

[10] Orlović S. (2002), Političke partije i moć, Čigoja, Beograd.

[11] Reljić, S. (2014), Kriza medija i mediji krize, Službeni glasnik, Beograd.

[12] Slavujević, Z. (2005) Politički marketing, Čigoja, Beograd.

[13] Tadić M., (2004) Osnovi međunarodne propagande, BINA, Beograd, 2002.

[14] Vujaklija M. (2004) Leksikon stranih reči i izraza, Prosvjeta, Beograd.

[15] http://geopolitika.news

[16] http://balkans.aljazeera.net/

[17] http://www.vijesti.me

[18] http://www.geopolitika.rs

[19] http://www.politika.rs

[20] http://www.rts.rs/ 